\title{
Menumbuhkan Calon Wirausaha di Perguruan Tinggi
}

\author{
https://doi.org/10.25008/parahita.v1i1.41
}

\author{
Zulhawati $^{1}$, Ifah Rofiqoh², Lia Faj'rina Binuril Hidayati ${ }^{3}$ \\ ${ }^{1,2}$ Fakultas Bisnis Psikologi dan Komunikasi, Universitas Teknologi Yogyakarta \\ Jl. Ring Road Utara, Mlati Krajan, Yogyakarta 55285 - Indonesia \\ ${ }^{3}$ Fakultas Ilmu Sosial dan Humaniora, Universitas Islam Negeri Sunan Kalijaga \\ Jl. Laksda Adisucipto, Yogyakarta 55281 - Indonesia \\ *Email Korespondensi: zulhawati@uty.ac.id
}

\begin{abstract}
Abstrak
Persaingan sumber daya manusia yang semakin ketat memaksa perguruan tinggi mepersiapkan lulusan yang harus memiliki kompetensi hardskill dan softskill. Untuk mengurangi pengangguran, kurang percaya diri, kurang pemahaman aktualisasi keilmuan, dan kendala lain yang dihadapi oleh lulusan perguruan tinggi, salah satu program yang dilaksanakan di UTY adalah memberikan bekal kewirausahaan. Program Pengembangan kewirausahaan (PPK) melalui berbagai tahapan merupakan suatu hubungan mahasiswa, kewirausahaan, dunia usaha dan UTY. Dukungan dan komitmen pengembangan kewirausahaan di UTY dikembangkan melalui Bidang Kreanopreneur meliputi kreativitas, inovasi dan kewirausahaan dengan memberikan dukungan inkubasi untuk tumbuh dan pembekalan mahasiswa dalam mengimplementasikan dunia usaha dan jiwa wirausaha.
\end{abstract}

Kata kunci: wirausaha, mahasiswa, kewirausahaan, dunia usaha

\section{PENDAHULUAN}

Masih banyak mahasiswa yang belum tergerak atau perduli dengan kondisi di luar lingkungannya, kurang dapat melihat atau membaca peluang inovatif yang bisa dikembangkan dalam rangka peningkatan keahliaan dan ketrampilan. Potensi mahasiswa yang belum memanfaatkan peluang dan waktu dalam mengisi kreatifitas berpikir dan beraktifitas masih terlihat dari kebiasaan hanya berangkat kuliah saja, main, game, menonton televisi dan berbagai hiburan lainnya. Untuk membuka pemikiran dan menyentuh kemampuan intelektual dan aktifitas mahasiswa perlu sarana dan cara agar kemampuan dan pemikiran mahasiswa bisa diaktualisasikan. Melalui Program Pengembangan Kewirausahaan (PPK) yang ditanamkan melalui kegiatan akademik dan non akademik di lingkungan UTY, diharapkan bisa mengerakkan potensi-potensi dan kreatifitas mahasiswa dalam mencapai kesuksesan baik belajar, berkarya dan berkarir.

Kegiatan yang telah dilakukan antara lain kompetisi proposal bisnis UTY enterpreneurship untuk mengugah minat dan motivasi mahasiswa agar mampu mandiri berwirausaha. Pengembangan kewirausahaan baik dari sisi akademik dan non akademik diharapkan akan mengubah pola yaitu lulusan perguruan tinggi sebagai pencari kerja menjadi pengembang, pencipta dan pembuka peluang lapangan kerja. Mahasiswa dan alumni UTY bisa berpikir lebih kreatif untuk mengembangkan diri dalam menghadapi berbagai persaingan kerja dan usaha yang semakin ketat. Kegiatan lain untuk menunjang keberhasilan wirausaha mahasiswa dengan melakukan mentoring (pendampingan dan konsultasi bisnis) dan temu wirausaha (gathering) untuk bisa memberikan warna dan suntikan motivasi bagi mahasiswa untuk selalu membuka wawasan dan kreatifitas dalam membangun pondasi karir selama sebagai mahasiswa dan bekal untuk setelah lulus.

Dengan model seleksi dari proposal dan presentasi bisnis yang memadai maka dari sekian banyak proposal yang masuk dari mahasiswa khususnya dari team PKM/PKMK yang sedang 
mengembangkan rintisan usaha tersebut dibimbing, diarahkan, dibantu manajemen dan dikuatkan dalam menjalankan atau mengimplementasikan bisnisnya. Mahasiswa dari semua fakultas dijaring dan disosialisasikan untuk mencoba membuat proposal usaha yang nanti akan dikembangkannya atau evaluasi dari kegiatan usaha mahasiswa yang sudah berjalan.

Kegiatan mahasiswa ini kebanyakkan dibuat dalam dua kategori yaitu kategori usaha yang akan dirintis (inkubator) dan kategori usaha bersama mahasiswa yang sudah berjalan.

Harapan dari Program Pengembangan Kewirausahaan ini akan bermunculan berbagai rintisan usaha oleh mahasiswa. Karena usaha mahasiswa ini masih di bawah lima tahun (balita) maka dukungan moral, manajemen, kemampuan supervisi yang kuat serta dukungan networking atau relasi sangat penting untuk menunjang eksistensi usaha tersebut. Berbagai kendala dan kelemahan sering dihadapi dalam menjalankan rintisan usaha.

\section{Rekrutmen tenant}

\section{METODE PELAKSANAAN}

Untuk mendapatkan calon wirausaha dilakukan rekrutmen tenant dengan melakukan pola seleksi dengan program proposal bisnis dan kunjungan ke program PKM/PKMK. Dilakukan sosialisasi dan seleksi proposal dengan kriteria penilaian yaitu pelaksanaan usaha yang layak dikembangkan dan semangat motivasi dari calon peserta merupakan patokan dasar dari diterimanya proposal bisnis tersebut. Pada tahap awal rekrutmen diambil mahasiswa dari beberapa jurusan yang sedang mengembangkan atau merintis usaha baru. Proposal-proposal bisnis yang masuk kemudian dilakukan seleksi. Adapun seleksi yang dilakukan meliputi seleksi administrasi, presentasi proposal bisnis, studi kelayakan dan kunjungan usaha bagi mahasiswa yang telah mengembangkan usaha.

\section{Pelaksanaan Program Pengembangan Kewirausahaan}

Tenan terpilih akan melakukan beberapa kegiatan berikut ini:

(1) Program pengembangan analisis proposal bisnis: pada program ini mahasiswa peserta tenant diberikan arahan berbagai langkah dalam menyusun proposal usaha yang baik mulai dari analisis situasi, membuka peluang, analisis produksi, analisis marketing, analisis sumber daya manusia serta analisis kelayakan dari tiap langkah proses kerja dalam usaha;

(2) Pelatihan pengembangan motivasi (AMT) dalam kegiatan ini semua peserta tenant akan diberikan pembekalan baik mental, motivasi, fisik serta spiritual dalam melangkah menjalankan usaha yang akan atau sedang dirintis. Dalam kegiatan ini peserta ditraining dengan materi: motivasi usaha, manajemen bisnis, mengatur fokus membangun cita-cita masa depan serta kemampuan membangun team dan komunikasi bisnis;

(3) Pelatihan kewirausahaan: pada pelatihan ini diberikan pelatihan bagaimana mengatur sumber daya manusia, produksi serta kemampuan pemasaran, disamping materi manajemen diberikan juga pengalaman praktis dari pengusaha sukses dalam bisnisnya;

(4) Pemagangan pada Industri Mitra. Program ini juga membantu para mahasiswa peserta tenant yang sedang merintis usaha atau membuka usaha diberikan pengetahuan dan pengalaman melalui kunjungan, magang dan mendatangkan praktisi yang sesuai dengan bidang yang digeluti oleh mahasiswa sehingga mahasiswa dalam menjalankan usaha dan bisnisnya bisa lebih memiliki wawasan yang luas, aspek Amati, Tirukan dan Modifikasi (ATM) bisa diterapkan dari program ini untuk diimplementasikan dalam program usahanya;

(5) Program Implementasi Usaha Mandiri, dari langkah-langkah yang sudah dilakukan secara matang dari survey, analisis bisnis dan persiapan material dan SDM, maka mahasiswa melakukan proses praktek/mewujudkan bisnis atau usaha sesuai dengan projek yang dikembangkan dengan lokasi, produk yang akan dijual, potensi pasar yang akan digarap serta manajemen usaha. Dari point ini Program Pengembangan Kewirausahaan terus memberikan arahan dalam menetapkan berbagai langkah terbaik dalam menyukseskan bisnis; 
(6) Pola Pembimbingan dan Evaluasi, dukungan serta arahan dari seorang pakar atau konsultan sangat berharga sekali didalam memberikan masukan dan saran bagi kemajuan suatu usaha. Program ini dilakukan agar arah dalam berusaha mandiri tetap terus berjalan dan makin berkembang;

(7) Pengawasan dan Supervisi bagi tenant, untuk melakukan evaluasi dan sharing sesama anggota tenan dan supervisor;

(8) Pola pemberian bantuan teknologi untuk mempercepat proses kesuksesan membangun usaha, baik barang, jasa atau layanan akan mudah di pemasarannya apabila dibantu dengan pemasaran lewat e-commerce, apabila usaha-usaha tersebut sudah bisa dibantu dalam membangun e-commerce informasi produk, jasa dan layanan lainnya akan semakin mudah dan cepat tersebar. Dengan bantuan program ini jelas akan membantu menghemat aspek distribusi dan tenaga kerja untuk menanggani pemasaran;

(9) Metode penyeleseian masalah Dalam pola pelaksanaan PPK ini metode pemecahan masalah dilakukan dengan melakukan analisis SWOT (Kekuatan, Kelemahan, Peluang dan Tantangan)

\section{Kolaborasi dengan lembaga mitra sejenis di luar kampus}

Program ini bertujuan untuk mengembangkan jejaring sesama lembaga sejenis di luar kampus serta bermitra dengan berbagai instansi swasta dan pemerintah untuk saling bersinergi dan kontribusi bersama dalam membangun kesuksesan program kerja. Untuk itu program ini terus terbuka dan selalu meningkatkan silahturahmi dengan lembaga mitra dari Perguruan Tinggi lain, lembaga pembiayaan usaha, lembaga sosial serta instansi pemerintah dan swasta serta kalangan pengusaha. Beberapa media kolaborasi dengan lembaga mitra sejenis dijembatani melalui kerjasama oleh Dinas Pendidikan Propinsi DIY dengan mengadakan kegiatan sharing kewirausahaan dan bisnis bagi Dosen di seluruh PTN-PTS se Propinsi DIY serta program Wirausaha Mahasiswa Propinsi DIY. Kerjasama dengan Bank Mandiri dalam program Wirausaha Mandiri. Kerjasama dengan Kadin dan HIPMI Propinsi DIY dan Kemenkop DIY.

\section{HASIL DAN PEMBAHASAN}

Program Pengembangan Kewirausahaan di UTY berhasil mempersiapkan calon-calon wirausaha di bidang kuliner, industri kreatif, dan fashion. Keberlanjutan program ini akan dikembangkan dengan membentuk wadah alumni Program Pengembangan Kewirausahaan UTY menjadi suatu komunitas wirausahawan sehingga bisa membina adik-adik tingkatnya dalam mengembangkan inkubator wirausaha di UTY yang bisa menjembatani mahasiswa untuk mengembangkan dan merintis usaha mandiri dan bisa memberikan solusi manajemen dan pembiayaan. Memanfaatkan fasilitas dan sarana untuk mengembangkan keahlian dan kreatifitas mahasiswa dalam memanfaatkan dan menumbuhkan usaha-usaha mandiri yang bisa dikelola saat masih menjadi mahasiswa atau setelah lulus.

\section{KESIMPULAN}

Dengan melakukan rekrutmen berupa seleksi, pengembangan dan analisis proposal, pelatihan dan pendampingan kewirausahaan, praktik kewirausahaan, pemagangan industri, implementasi, pendampingan dan pemberian bantuan teknologi sampai konsultasi pemecahan masalah serta membuat kolaborasi dengan lembaga mitra di luar kampus untuk mengembangkan jejaring dapat digunakan sebagai penggerak calon wirausaha dari kampus.

\section{Ucapan Terimakasih}

Terimakasih kepada Kemenristek Dikti dan LPPM UTY yang telah memberikan kesempatan dan dukungan dana dalam pelaksanaan Program Pengembangan Kewirausahaan. 


\section{Daftar Pustaka}

Hermawan, K. (1994). Marketing Plus 2 Jalur Sukses untuk Bisnis, Jakarta: Pustaka Sinar Harapan.

Jackly, L. (2009). 101 Kunci Sederhana Mengembangkan Bisnis dari Rumah, Yogyakarta: Bookmarks Press.

John, C.M. (2002) The 17 Essential Qualities of a Team Player, Jakarta: Prestasi Pustaka.

Hutagalung, I \& Ritonga, R. (2018). Pengaruh Iklim Komunikasi dan Komitmen Organisasi terhadap Kepuasan Kerja Pegawai Kecamatan XYZ Bekasi, Jurnal Kajian Komunikasi, 6(2), $72-84$.

Kasali, R. (2011), Wirausaha Muda Mandiri, Jakarta: Gramedia Pustaka Utama.

Kasali, R. (2012). Re-Code Your Change DNA, Jakarta: Gramedia Pustaka Utama

Mansur, Y. (2012). Semua Bisa Jadi Pengusaha, Jakarta: Zikrul Hakim

Nurastuti, W. (2011). Teknologi Perbankan, Yogyakarta: Graha Ilmu

Ritonga, R \& Syahpurta, I. (2019). Citizen Journalism and Public Participation in the Era of NewMedia in Indonesia: From Street to Tweet, Media and Communication, 7(3), 79-90

Ritonga, R., Murwani, E., \& Ritonga, S. (2017) Gender Awareness of Maria Hartiningsih as Daily Kompas Reporter, Jurnal Komunikasi Ikatan Sarjana Komunikasi Indonesia, 2(2), $82-91$

Rohkmat. (2012), Manajemen Pemasaran, Yogyakarta: Kalam Press

Zulhawati \& Ifah, R. (2014). Manajemen Keuangan dan Etika, Yogyakarta: Pustaka Pelajar

Zulhawati d\& Ifah, (2016). Penganggaran dan Etika Bisnis, Yogyakarta: Pustaka Pelajar 